\title{
A Munkácsi Görögkatolikus Egyházmegye újraengedélyezése
}

\author{
Re-Enablement of the Greek Catholic Diocese of Munkács
}

Majorossy Mária

https://doi.org/10.47707/Kulugvi Szemle.2021.4.5

Összefoglaló: A függetlenségét elnyert Ukrajna társadalmi-politikai fejlődésének fontos részét képezte az egyházak immár szabadabb keretek közötti szerveződése. Bár a történelemtudományban viszonylag kevés szerepet kap, a görögkatolikus egyház restitúciója az egyik meghatározó elem volt az ország demokratikus változásai útján. Az egyházkérdés - és kiváltképp a Munkácsi Görögkatolikus Egyházmegyéé - jelenleg is komoly társadalmi súllyal bír, hiszen a vallási jellegén kívül egyre erősebb kimondottan politikai töltettel is rendelkezik. Ukrajna társadalmi-politikai fejlődésének vizsgálata szempontjából elengedhetetlen tehát a vallási szerkezetében zajló folyamatok ismerete is.

Kulcsszavak: Ukrajna, Munkácsi Görögkatolikus Egyházmegye, görögkatolikus egyház, vallás

Abstract: An important part of the socio-political development of the newly independent Ukraine was the more liberal organization of the churches. Although it plays a relatively small role in historical science, the restitution of the Greek Catholic Church has been one of the defining elements of the country's democratic changes. The issue of the church - and especially that of the Greek Catholic Diocese of Munkács Mukachevo - still has a serious social weight, as in addition to its religious character, it also has an increasingly strong political charge. Knowledge of the processes laking place in its religious structure is therefore essential for examining the socio-political development of Ukraine.

Keywords: Ukraine, Greek Catholic Dioces of Munkács, Greek Catholic Church, religion

A Munkácsi Görögkatolikus Egyházmegye története korántsem vi szontagságoktól mentes. A görögkatolikus egyháznak (GKE) a fennállása óta számos gonddal és akadállyal kellett megküzdenie. Elég 
csak megemlíteni a püspökség 1949-es feloszlatását és a későbbi üldöztetését. Azonban a görögkatolikus papság minden tiltás és aka dály ellenére továbbra is aktívan múködött az „illegalitásban”. Ennek köszönhetően vált egyértelművé, hogy a Munkácsi Püspökség és Görögkatolikus Egyház legalizálásáért és rehabilitálásáért folytatandó mozgalom megindulása már csak idő kérdése. A megfelelő alkalom az 1980-as évek második felében, illetve a kilencvenes évek elején érkezett el, amikor is Mihail Gorbacsov kihirdette a „peresztrojkát”, amely a társadalom demokratizálását és az állam egyházpolitikájának a liberalizálását helyezte kilátásba. A Kijevi Rusz keresztény hitre térésének (988) közelgő millenniuma mellett ez adta meg a jelet a GKE törvényesítését elősegítő mozgalom megkezdéséhez. A görögke leti vallást Ukrajnában két egyház képviselte: az Ukrán Görögkatolikus Egyház (UGKE) és a Munkácsi Görögkatolikus Egyházmegye.

Annak ellenére, hogy a GKE engedélyezésének kérdése viszonylag új témának számít mind az ukrán, mind a külföldi történelmi szakirodalomban, az nemegyszer szóba került már az Ukrajna egyetemes történelmével foglalkozó tudósok között. Bár nem kevés azon múvek száma, amelyek részlegesen tárgyalják e kérdéskört (ld. Gurkina, 2014; Bendik, 2006; Bendász, 2012; Keleher, 1993; Fenych, 2019; Botsurkiv, 1993; Bublyk, 2012), Kossej, 2000), mégsem beszélhetünk a téma egységes és rendszerezett kutatásáról. Mivel a folyamat a közelmúltban ment végbe, számosan tanúként voltak jelen a kezdeteinél, de azóta, sajnos, közüilük sokan elhunytak már. Ezért is számít rendkívïl fontosnak az a forrásbázis - dokumentumok, a korabeli média anyagai, interjúk, azon papok és hívek elbeszélései, akik az események köz vetlen résztvevői voltak, valamint rengeteg fénykép- és videóanyag -, amelynek egy részét Lemberg, illetve Ungvár archívumaiban sikerült tanulmányozni.

A jelen elemzésben azon főbb eseményeket igyekszem bemutatni, amelyek a GKE legalizálásának a folyamatát készítették elő, és az elért sikerek mellett a Munkácsi Görögkatolikus Egyházmegye engedélyez tetése közben történt kudarcokra is fény derül. Az egyházmegye újjászületése az illegalitásban múködő GKE papjai és hívei fáradhatatlan 


\section{Külïgyi Szemle}

munkájának, töretlen lelkierejének a gyümölese, akik nem adták fel a hitüket a fenyegetések és tiltások ellenére sem.

Eleinte úgy tűnt, hogy a Munkácsi Görögkatolikus Egyházmegye és az Orosz Pravoszláv Egyház 1949. februári „egybeolvasztása” a kárpátaljai görögkatolikusok számára semmilyen esélyt sem adott a túlélésre: a püspökség gyakorlatilag vezetô nélküil maradt, amikor Hira Sándor püspököt letartóztatták és száműzték a megye terüle térôl (Bendász, 2012), a papság egy része áttért a pravoszláv hitre, a többieket letartóztatták, a hívek pedig a lelki vezetőik nélkül más templomokba kezdtek el járni, vagy otthon imádkoztak. De ez nem tartott sokáig. Idôvel azok, akiket nem tartóztattak le, titokban elkezdték szervezni a munkácsi egyházmegye görögkatolikusainak a lelki életét. Mint tudjuk, a legalizálás egy hosszú folyamat, amely fokozatosan ment végbe, és sokszor a politikai helyzettől, illetve az általános társadalmi hangulattól is nagyban függött.

Az egyházmegye elismertetésének a reménye sohasem hagyta el az illegalitásba vonult papság és a hívek szívét. Amint Nyikita Hruscsov az 1950-es évek második felében bejelentette a „desztalinizációt”, azonnal próbálkozások kezdődtek a görögkatolikus közösségek be jegyzésére, s hogy hivatalosan is elismertessék a Kárpátalján mú ködő görögkatolikus egyházat - azonban az igyekezet hasztalannak bizonyult (Bendász, 2012). Amikor például az egyik pravoszláv pap át tért a görögkatolikus vallásra (Kiskopány (Alsóveresmart) községben, a Nagyszőlősi járásban), csak rövid időre okozott zavart az oly biztos alapokon nyugvó pravoszláv egyház életében. 1956 októberében a falu parókusa, Anton Bacskaj hivatalosan is bejelentette a Munkácsi Pravoszláv Egyházmegye vezetőségének, hogy a továbbiakban nem hajlandó a pravoszláv rítus szerint bemutatni a szentmiséket, és áttér „arra a vallásra, amelyben megkeresztelték, és amelyet hosszú ideig gyakorolt is" (Az Ukrán Biztonsági Szolgálat Levéltára, 1957, 20. o.). Természetesen ez a helyi vezetőség nemtetszését váltotta ki, és már 1957 februárjában letartóztatták Anton atyát az Állambiztonsági Minisztérium munkatársai. A nyomozást, a kihallgatásokat és a tárgyalást követően kimondták az Ukrán Szovjet Szocialista Köztársaság 
büntetőtörvénykönyve 2. §-ának 10-54. cikkelyei és 1. §-ának 21-56. cikkelyei szerinti bűnösségét, és 7 év letöltendő fegyházbüntetést szabtak ki rá, a személyi vagyontárgyai elkobzásával (Az Ukrán Biztonsági Szolgálat Levéltára, 1957, 341. o.). Bár az eset nagy társadalmi visszhangot váltott ki, azt a GKE újjászüiletésének ügyében mégis tízéves hallgatás követte.

A következő esemény, amely új reményt adott Kárpátalján, a GKE 1968-as csehszlovákiai engedélyezése lett. A munkácsi papság felbuzdult a hír hallatán, és nagy reményekkel várták, hogy nemsokára az ő egyházmegyéjük kapcsán is hasonló örömteli döntés születik majd. Így emlékezik erről Joszip Holovács püspök: „Bennünk mindig élt a remény... Így maradtam kapcsolatban a legtöbb pappal, és mindig vár tuk, hogy az átterjed ide is... Úgy, hogy ne érjen bennünket felkészületlenül... Igaz, én sokat utaztam Csehszlovákiába, és ott is püspökként teljesítettem szolgálatot... Részt vettem Eperjesen és Magyarorszá gon..." (Az Egyháztörténeti Intézet Levéltára, 1990). A csehszlovákiai történések, ha nem is azonnal, de mindenképpen hatást gyakoroltak az emberekre, akik a saját egyházuk rehabilitációjának a lehetőségét dédelgették: megerôsítette a pozícióikat, és táplálta a bizakodásukat.

Sajnálatos módon, az Ukrán Szovjet Szocialista Köztársaságban. amelyhez akkor Kárpátalja is tartozott, semmilyen lépések nem tör téntek a görögkatolikus egyház engedélyezése érdekében. Majdnem 20 év telt el a Csehszlovákiában történtek után, de végüil az „újjá születés tavasza" Munkács környékét is elérte. A helyi egyházmegye püispöke, Szemedi János így emlékszik vissza:

„Látják, ez az időszak nálunk már régóta közeledett. Már '87ben voltunk Moszkvában; püspökök, papok, hívek gyúltek akkor össze ott, hogy követeljünk. Kifejtettük, hogy nálunk szörnyű paradox helyzet alakult ki: két kilométer választ el Csehország tól, néhány pedig Magyarországtól, Lengyelországról már nem is beszélve - ahol az emberek szabadon imádkoznak. A mieink átjárnak Csehszlovákiába, mert ott nyíltan imádkozhatnak, ná lunk pedig nem szabad. Gorbacsovnak állandó jelleggel küild tünk kérelmeket, írtunk a moszkvai Egyháztanácsnak is." (Az Egyháztörténeti Intézet Levéltára, 1993) 


\section{Külïgyi Szemle}

1982-ben megtették az első bizonytalan lépéseket a cél elérésének - a GKE hivatalos elismertetésének - hosszú útján. Szeptemberben Galíciában megalakult a Hívők és Egyházak Jogainak Védelmét Kezdeményező Csoport Ukrajnában, amelynek első elnöke a kárpátaljai származású Joszip Terelja lett. A csoport fő feladata a görögkatolikus közösségek hivatalos bejegyeztetésének a segítése volt. A szervezet békés módszerekkel küzdött a felvállalt feladata teljesítéséért: röplapokat osztogatott, és „A Katolikus Egyház krónikája Ukrajnában” címú kiadvánnyal próbálta felhívni a lakosság figyelmét, valamint az összukrajnai és a kárpátaljai katolikus egyház problémáját a Szovjetunió határain kívuil is megismertetni. Az aktivista tevékenységéért Terelját már decemberben letartóztatták - először egy, 1985-ben pe dig hét évre. Az általa elkezdett ügyet Vaszil Kobrin folytatta - mindaddig egész sikeresen, amíg, 1984 novemberében, ôt is el nem ítélték háromévnyi kényszermunkára (RISU, 2011). Tevékenysége során Joszip Terelja szoros kapcsolatot tartott fenn Ivan Marhiticcsal, aki a Munkácsi Egyházmegye engedélyezéséért indított mozgalmat szervezte (Az Egyháztörténeti Intézet Levéltára, 2000). Bár a szövetségüiknek nem sikerült elérnie a végső célkitűzésüiket, az aktivistái jelentős mértékben hozzájárultak az ügy előmozdításához.

Amikor a nyolcvanas évek második felében végre egy kedvezőbb politikai helyzet alakult ki, Ukrajna - azon belïl is főleg Kárpátalja görögkatolikusai radikális lépésre szánták el magukat, amihez ösz tönzésül a már említett csehszlovákiai és lengyelországi események szolgáltak. Ugyanebben az időben alakult ki az új irányú „gorbacsovi” politika, amely a társadalom demokratizálását hirdette meg, továbbá ekkortájt érkezett el a Kijevi Rusz (a Kijevi Nagyfejedelemség) keresztény hitre térésének az 1000. évfordulója, valamint egy újgenerációs papság volt születőben, akik már a II. Vatikáni Zsinat szellemében ne velkedtek, s így új szemléletet hoztak az egyház további fejlődésébe.

1987-től az engedélyeztetésért indult mozgalom megújult: szer vezettebbé, dinamikusabbá vált, egyre nagyobb tömegeket vonzott be, és minôségileg újabb szintre lépett. A legjelentősebb esemény az illegalitásból való visszatérés bejelentése és a II. János Pál pápának 
szóló, az egyház hivatalos elismerésre vonatkozó kérelem megírása volt, amelyet 1987. augusztus 4-én hoztak nyilvánosságra. A kérelem végén két püispök - Galíciából Pavlo Vasziliké és a munkácsi Szemedi Jánosé -, továbbá 23 pap, szerzetes, apáca és közel 150 hívő aláirása szerepelt (Botsurkiv, 1993). A kérelem másolatát eljuttatták a Szovjet unió elnökéhez, Mihail Gorbacsovhoz is. Ekkor jelentették be először az illegalitásból való kivonulást és a legitim múködés iránti kérelmet:

„Mi, püspökök, papok, szerzetesek és apácák, hűek vagyunk az Ukrajnai Katolikus Egyházhoz mindnyájan, akik aláírtunk, bejelentjük, hogy a Szovjetunió átépítésével kapcsolatban és a kedvezőbb körülmények hatására, valamint Ukrajna keresz tény hitre térésének 1000. évfordulója tiszteletére úgy gon doljuk, hogy nem célszerú tovább illegalitásban múködnünk: ezért kérjük Öszentségét, tegyen meg mindent az Ukrajnai Görögkatolikus Egyháznak a Szovjetunióban történő szabá lyos engedélyeztetése érdekében. Egyidejűleg Ôszentsége köz vetítésével fordulunk a Szovjetunió kormányához az Ukrajnai Görögkatolikus Egyház egy részének az illegalitásból való kivonulását illető bejelentésünkkel." (A szerző személyes archívuma, 1987)

1987 decemberében újraszervezték az Ukrán Katolikus Egyház Védelmi Bizottságát, amelyet a korábbi disszidens, Ivan Hel vezetett, aki a kezdeményezők ügyét vitte tovább: a Vatikánhoz, az állami szer vekhez és a küllföldi egyházi szervezetekhez intézett folyamodványaiban arra kért mindenkit, ismerjék el hivatalosan az Ukrajnában létező görögkatolikus egyházat (Bublyk, 2012). A védelmi bizottságban Kárpátalját Ivan Marhitics püspök képviselte, aki, mint elmondta, az 1987-ben Moszkvába induló első küildöttséget - amelynek ő maga is a tagja volt - éppen a bizottság delegálta:

„Szóval, amikor mi először utaztunk Moszkvába a bizott ság akkori elnökével, Ivan Hellel, akkor Ohorodnyikov - a hí res riporter és újságíró - lakásán jelen volt Lev Jakunyin is. Ohorodnyikov és Lev Jakunyin szervezték a lakáson tartott sajtótájékoztatót. Kilenc országból voltak jelen képviselők és 


\section{Külïgyi Szemle}

riporterek. Köztük volt Hollandia tudósítója is... Vele együtt jött a sajtótájékoztatóra Hollandia nagykövete is." (Az Egyháztörté neti Intézet Levéltára, 2000)

Az említett sajtótájékoztató fő témái a következők voltak: az ille galitásban múködô egyház helyzete, a Lembergi Zsinat törvénytelen sége és a GKE állami és nemzetközi szinten való elismerése.

Aztán elérkezett végre a várva várt 1988-as év is - a Rusz ke resztény hitre térésének 1000. évfordulója. A GKE engedélyezésé ért küzdők számára lelki felemelkedést jelentett II. János Pál pápa Manum Baptismi Donum [A keresztség nagy ajándéka] című, a jeles esemény alkalmával 1988. február 14-én kelt üzenete (John Paul II, 1988), amelynek lényeges mondanivalója, hogy az egyház történelmében már máskor is voltak egyedülálló törekvések az egység elérésére, mégpedig teljesen jogosan.

Most már a kárpátaljai görögkatolikusok is megtették az első nyílt lépéseket az engedélyeztetés érdekében: a hívek tömeges aláírásgyứjtésbe kezdtek, hogy bejegyeztessék a saját parókiájukat, és a petícióval Moszkvába utaztak. (Csupán 1988 elsô negyedében több mint tízezer aláírás gyưllt össze Kárpátaljáról és Galíciából; a helyi önkormányzatokhoz és a Szovjetunió Minisztertanácsának kötelékében múködő Vallási Ügyek Tanácsa. Csak Kárpátaljáról húsz kérelem futott be a görögkatolikus közösségek bejegyzésének érdekében. [Kobuta, 1999].) A papok elkezdték a hívek toborzását is, és elkezdték a közös szentmisék tartását. Az első nyilvános szentmise 1988 nagypéntekén zajlott, Ungváron, a Kálvárián, amelyen részt vett Szemedi is, bár még nem püspökként. (Kossej, 2001). Így indult el az a hullám, amelynek következtében az egész vidéken a görögkatolikus rítus szerint kezdték bemutatni a miséket.

Ezek után egyre több hívő gyưlt össze Ungváron és Kárpátalja más városaiban, falvaiban, akik a szabad ég alatt vagy az egykori templomaik udvarán, esetleg a temetőkben mutatták be a közös szentmise áldozatot. Azonban a helyi hatalom és jogvédő szervek nem tudtak megbékélni ezzel a tömeges jelenséggel, és minden lehetséges módon 
igyekeztek megakadályozni a hívők tömeges találkozóit - egyeseket akár 15 napig terjedő időre is letartóztattak, másokra pénzbírságot szabtak ki. Az egyik legnagyobb rendőri incidens 1988-ban, Boronyava (a Huszti járásban levő, egykori Husztbaranya) község férfikolostorának a romjainál történt, ahová egész Kárpátaljáról és Galíciából várták a híveket (Az Egyháztörténeti Intézet Levéltára, 1994). A rendőrség azonban lezárta az összes utat, nem engedték át a buszokat, és szétoszlatták az összegyúlt tömeget. Hasonló eset történt ugyanabban az évben az ilosvai Bilke községben is, ahol a hívek, élükön Pavlo Magyarral, a lezárt templom előtt szerettek volna misét bemutatni Petro Orosz atya emlékére. A falut bekerítette a rendőrség, senkit sem engedtek se ki, se be (Az Egyháztörténeti Intézet Levéltára, 1994). Az ilyen intézkedések egész Kárpátaljára jellemzőek voltak.

Majdnem az egész évben szerveződtek a Moszkvába induló püs pöki, papi és hívői küldöttségek, akiknek továbbra is az volt a céljuk, hogy kijárják a görögkatolikus közösségek bejegyzését (Az Egyháztörténeti Intézet Levéltára, 2000). De minden hasztalannak tűnt. Erről tanúskodik az az eset, amely az egyik kárpátaljai küldöttséggel történt Moszkvában, amelynek Ivan Marhitics püspök is a tagja volt. Azért utaztak a szovjet fóvárosba, hogy a Vallás Ügyek Tanácsaban bejegyeztessék Borzsavszke (egykor Nagycsongova) község görögkatolikus parókiáját, ám a következôvel zárult:

„1988-ban történt az eset... Ukrajna megkeresztelésének 1000. évfordulójának ünneplése már a végéhez közeledett... Széles mosollyal közeledtek felénk, és azt mondták, a közösség bejegyzése már megtörtént... És amikor sorra kerültüink, kiderüilt, hogy az Orosz Pravoszláv Egyház közösségét jegyezték be Borzsavszkéban." (Az Egyháztörténeti Intézet Levéltára (2000)

1988 júniusában történt azonban még egy jelentős esemény: két galíciai püspöknek, Pavlo Vasziliknak és Filimon Kurcsabának az olasz Agostino Casaroli és a holland Johannes Willebrands bíborossal való moszkvai találkozója. Az utóbbiak a Rusz keresztény hitre térésének 1000. évfordulójára érkeztek a fővárosba (Botsurkiv, 1993). 


\section{Külïgyi Szemle}

A püspököknek egyetlen céljuk volt: nyíltan bejelenteni a GKE múkö dését, és az egyház állami elismerését szorgalmazni.

Ezzel egyidejúleg Kárpátalján folytatódtak a tömeges tüntetések és a közösen bemutatott szentmisék. A Szentkereszt magasztalásának ünnepén (1988. szeptember 27.) Szemedi püspök a székesegyház falainál mutatta be az elsô püspöki szentmiséjét (Botsurkiv, 1993). Ivan Marhitics püspök pedig további szentmiséket celebrált a szüilőfalujában, Borzsavszkében (Nagycsongván), a lezárt templom előtt.

Mindebból jól látható, hogy a Kijevi Rusz millenniumi ünnepségei igencsak aktívan zajlottak, amely - mondhatni - a görögkatolikusoknak a jogaikért folytatott küzdelmüik csúcspontját jelentette. A hatalmas erőfeszitések ellenére mégsem 1988 lett a GKE hivatalos elismeré sének az éve. Azonban jelentős mérföldkőnek bizonyult az ügy előmozdításában. Akkoriban készítették elő mindazt, ami a GKE 1989-es engedélyezését lehetővé tették: a szervezett tüntetések, megmozdulások hatásosnak bizonyultak - társadalmi jelentőségű üggyé emelték a kérdést, s ezzel felkeltették a világ figyelmét.

A következő év döntőnek bizonyult a görögkatolikusok elismeréséért folytatott küzdelemben, és le is zárta azt, mégpedig egy logikus megoldással.

1989-ben még néhányszor utaztak küldöttek Moszkvába. Kárpát aljáról a delegáltak között volt Szemedi János és Ivan Marhitics püs pök, a papság részéről Pavlo Magyar, Mikola Sepa, Miron Beszkid és Fedor Sztepan atya, és velüik tartott néhány tucat aktív hívő (Az Egyháztörténeti Intézet Levéltára, 1996). A küldöttségeket nagyjából 50 fö alkotta, így a kárpátaljai görögkatolikusok a galíciai társaikkal továbbra is megtettek mindent egyházuk ügyéért.

Amikor e megmozdulások szinte teljesen eredménytelennek bi zonyultak, a görögkatolikus hívek, élüikön a galíciai Pavlo Vaszilik, Filimon Kurcsaba és Szafron. Dmiterko püspökkel, 1989 májusában a moszkvai Arbat utcán éhségsztrájkba kezdtek a követeléseik telje síttetése érdekében (RISU, 2011). Sajnos azonban, a tüntetők soraiban senki sem volt a Munkácsi Egyházmegyéből. A sztrájk őszig tartott, és más megmozdulások is kísérték: Ukrajna-szerte több városban és 
faluban zajlottak tüntetések. Ez viszont még nem jelentette azt, hogy a pravoszlávok tömegesen tértek volna át a görögkatolikus vallásra.

GKE engedélyezéséért küzdők imái végre meghallgatásra kerüil tek, amikor nyilvánosságra hozták a következő nyilatkozatot 1989 novemberében:

„A Vallási Ügyek Tanácsa bejelenti, hogy a görögkatolikusok - az Ukrajnai Szovjet Szocialista Köztársaság Alkotmányát és a vallásokról szóló hatályos törvényeit betartva - gyakorolhatják mindazon jogaikat, amelyeket az Ukrán SZSZK törvényei a vallási felekezeteknek biztosítanak."(Kossej, 2001)

Mindezt nemzetközi szinten 1989. december 1-jén erősítette meg Mihail Gorbacsov és II. János Pál pápa azon a találkozójukon, amellyel megkezdődött a Szovjetunió és a Vatikán diplomáciai kapcsolatainak a hivatalos felvétele. A vezetők azonnal bejelentették a görögkatolikus közösségek bejegyzésének az engedélyezését, amelyek ezzel elérték a legföbb céljukat (The Ukrainian Weekly, 1989).

Annak ellenére, hogy a görögkatolikusok eljutottak a bejegyzésüik engedélyezéséhez, azzal még csak a csatát nyerték meg, nem a háborút. Hiszen még nem oldódott meg véglegesen sem a GKE újjászüiletésének, sem az ellene irányult bűnök jóvátételének az ügye. Hátravolt még az Orosz Pravoszláv Egyház vezetősége részéről kinyilvánítandó elismerés és az egyházi javak visszaszerzése. Ezért 1990 elején megalakult a Négyoldalú Közös Bizottság, amely a nyugat-ukrajnai görögkatolikusok és pravoszlávok viszonyát volt hívatott rendezni és a vitás felekezeti kérdéseket megoldani. A bizottság tagjai a Vatikán, az Orosz Pravoszláv Egyház, az Ukrajnai Pravoszláv Egyház és az Ukrajnai Görögkatolikus Egyház képviselői voltak (A szerző személyes archívuma, 1990). Sajnos, a bizottság munkája nem hozta meg a várt eredményeket: a görögkatolikusok követeléseit nem teljesítették.

Az események felgyorsítása érdekében Volodimir Szternyuk metropolita vezetésével már 1990. január 23-án megkezdődött Lembergben a püspökök, a papság és a világiak zsinatja a helyi Urunk Színe változása templomban, ahol megjelent a Szemedi vezette munkácsi 


\section{Külïgyi Szemle}

küldöttség is (Kossej, 2000). A résztvevők elítélték az 1946-os lem bergi zsinatot, elemezték az illegalitásban töltött években folytatott tevékenységet, és megbeszélték a GKE végleges engedélyezését szor galmazó további intézkedéseket.

Június 25-27-én Szemedi János, Joszip Holovács és Ivan Marhitics püspök részt vett a görögkatolikus egyházatyák Rómában megrende zett szinódusán, amelyen a GKE engedélyezése volt a fö téma, első sorban azon események értékelése, amelyek elősegítették az ügyet, valamint a jövőbeli teendők megbeszélése és annak eldöntése, hogy miképpen mutassák be a görögkatolikusok tevékenységét a világnak (Kossej, 2000). Ez volt a görögkatolikus papság első szinódusa a GKE 1946-os likvidálása óta. A rendezvényen a Munkácsi Egyházmegye élére Szemedit nevezték ki, Holovácsot és Marhiticsot pedig az aszszisztenseivé. Ugyanakkor a három görögkatolikus püspök, János, Joszip és Ivan hatalmi jogkörét csak 1991. május 18-19-én, az ukrajnai GKE feje, Miroszlav Lubacsivszkij bíboros kárpátaljai látogatása so rán ismerték el hivatalosan (Kossej, 2000). Akkor tett nyilvános esküt Krisztus Egyházának a három püspök, amit pápai bullákkal is hitele sítettek.

A hivatalos ügyek befejezése után a megújult egyházmegyében elindult a munka. Már 1990-ben bejegyezték a Munkácsi Görögkatolikus Egyházmegye kapituláját (a püspök tanácsadó testülete, amely a klé rus felső vezetőiből áll) és alapszabályzatát. Az egyházmegye köz pontjául Ungvárt tették meg (Kossej, 2000), ahol hamarosan meg tartották a papság első tanácskozását. Megkezdôdött a legfontosabb feladatok végrehajtása: újraindították a papi szeminárium múködését (az új épüilet alapkövét június 28-án rakták le); mindent elkövettek az egyházi tulajdonok - többek között a kárpátaljai görögkatolikusok fő szentélyének, a Szent Kereszt felmagasztalásának székesegyházának visszaszerzéséért (a templomot 1990. október 13-án kapták vissza); előkészítették az egykor a GKE berkeiben szolgálatot teljesített már tírok boldoggá avatási folyamatát (elsősorban Romzsa Tódor püspö két); megalapították a püspökség saját újságát, a Blahovisznikot, és még számos más eredményt lehetne említeni. 
Ebben a nehézségekkel tűzdelt és hosszú folyamatban a Munkácsi Egyházmegyének segitő kezet nyújtott a már korábban engedélyezett hajdúdorogi és eperjesi testvérközösség, valamint fontos támogatás érkezett a Pittsburghi Metropóliától [fỏegyházmegye] is, amelynek tagjai a Kárpátaljáról a 19. század végén kivándorolt görögkatolikusok leszármazottai. Továbbá el sem képzelhető, milyen lelkesítő hatással volt a Munkácsi Görögkatolikus Egyházközség papságára és híveire a II. János Pál pápával történt találkozásuk Máriapócson (a kárpátaljai hívơk zarándokhelye), 1991 augusztusában, valamint Szlovákiában, 1995 júliusában, amikor is Ôszentsége a görögkatolikusokat a keresz tény hitükben állhatatos embereknek nevezte, és minden kezdemé nyezésükre az áldását adta (Kossej, 2000).

Azonban GKE-nek a illegalitásból való hivatalos kivonulását köve tően sem lélegezhettek fel teljesen a papok és a hívek. Még rengeteg munka várt rájuk: az egyházmegye rendszerének a kiépítése, az egyházi javak visszaszerzésének folytatása, új templomok építése, a papság új generációjának a felkészítése, a II. Vatikáni Zsinat szellemisé gének bevezetése. Ezek voltak azok a legfontosabb feladatok, amelye ket az újraengedélyezett egyházmegye katolikusainak még meg kellett oldaniuk. A nehézség abban állt, hogy nemcsak újjá kellett éleszteni az egykori egyházat, hanem arra is szükség volt, hogy megőrizzék, továbbvigyék és bővitsék az illegalitás idején felhalmozott eredményeket, s továbbra is becsületesek maradjanak a pravoszlávokkal való ellentétek során...

Az engedélyezés folyamata nagyon kimerítő és hosszú út volt. Még a mozgalom vezetỏi, aktivistái között sem volt teljes egyetértés. Két csoport alakult ki: a mérsékeltek és a radikálisok, akiknek a hare során használandó módszereket illetően is eltért a véleményük. Azonban ez nem akadályozta meg a közös cél elérését, és a görögkatolikus egyház papságának végül is sikerült mozgósítania az erőit, és egységben kitartani a végsőkig.

A Munkácsi Görögkatolikus Egyházmegyének az illegalitásból való visszatérése óta több mint harminc év telt el. Ez idő alatt annak vezetése, papsága, hívőközössége és a civil szervezetek a közös 


\section{Külïgyi Szemle}

erőfeszitéseiknek köszönhetően hatalmas munkát vittek végbe, noha sok kérdést máig sem sikerült véglegesen tisztázni. Azonban nyugodtan kijelenthető, hogy az egyházmegye ma újra fejlődik és virágzik.

\section{I rodalomjegyzék}

A szerző személyes archívuma (1987). Ukrán katolikusok egy csoportjának, a püspökök, papok, szerzetesek, apácák és az ukrán katolikus egyház híveinek II. János Pál pápához intézett nyilatkozata (Заява групи українщів католиків з Украйни Святійтому Отиеві Івану-Павлу II, Папі Римському від єпископів, священиків, монахів, монахинь і вірних Української Католииької Церкви) (a nyilatkozat másolata).

A szerző személyes archívuma (1990). Az ortodox és a görögkatolikusok közötti nyugat-ukrajnai kapcsolatok rendezéséről szóló négyoldalú vegyes bizottság elsö ülésének közös nyilatkozata (Спільна заява першої зустрічі Чотирьохсторонньої Спільної Комісії про врегулювання відносин між православними і греко-католиками в Західній Україні) (másolat).

Az Egyháztörténeti Intézet Levéltára (1990). Interjú Joszif Holovachcsal, Onokóc, 1990. 05. 29. (Інтерв’ю з вл. Йосифом Головачем від 29.05.1990, с. Оноківці, Закарпатська обл.) АІІЦ, П-1-1-1216.

Az Egyháztörténeti Intézet Levéltára (1993). Interjú Szemedi Jánossal, Ungvár, 1993. 11. 20. (Інтерв’ю з єп. Іваном Семедієм від 20.11.1993, м. Ужгород, Закарпатська обл.) АІІЦ, П-1-1-229.

Az Egyháztörténeti Intézet Levéltára (1994). Interjú Petro Magyarral, Bilke, 1994. 11. 30. (Інтерв’ю з о. Павлом (Петром) Мадяром, ЧСВВ від 30.11.1994, с. Білки, Закарпатська обл.) АІІЦ, П-1-1-499.

Az Egyháztörténeti Intézet Levéltára (1996). Interjú Miron Beszkiddel, Munkács, 1996. 06. 05. (Інтерв’ю з о. Мироном Бескидом від 05.06.1996, м. Мукачево, Закарпатська обл.) АІІЦ, П-1-1-687.

Az Egyháztörténeti Intézet Levéltára (2000). Interjú Ivan Marhiticcsal, Nagycsongova, 2000. 08. 03. (Інтерв’ю 3 вл. Іваном Маргітичем від 03.08.2000, с. Боржавське, Закарпатська обл.) АІІЦ, П-1-1-1148.

Az Ukrán Biztonsági Szolgálat Levéltára (1957). Bacskai Antonij Fedorovics elleni vádak. 3378. sz. ügyirat. A Szovjetunió büntető törvénykönyve, 1957. 01.31--1957. 03. 27. Az UBSZL kárpátaljai régiót érintő archívuma, fond 7., op. 1, 5507. sz. ügyirat, 370. о. (Дело № 3378 по обвинению Бачкая Антония Федоровича в пр.пр. ст. ст. 54-10 ч. II и 56-21 ч. I УК УССР. 
31.01.1957 - 27.03.1957, в 1 томі. Архів УСБУ в Закарпатській області, Ф. 7, Оп. 1, Спр. 5507, 370 арк.).

Bendász Dániel (2012). Lelkész káderképzés a Munkácsi Görögkatolikus Egyházmegyében (1949-1989) (Бендас Даниїл. Виховання духовних кадрів у Мукачівській греко-католицькій єпархї̈ [1949-1989]). Ungvár: Ungvári Nemzeti Egyetem, 6-33 o.

Bendik, Miron (2006). Az 1946-os lembergi pszeudozsinat és a „katolikuspravoszláv" probléma az Ukrán Görögkatolikus Egyház újjászületése idején, az 1990-es évek elején (Львівський псевдособор 1946 р. і «католицькоправославна» проблема в добу відродження УГКЦ початку 90-х рр. XX ст.). Дрогобицька духовна семінарія. A letöltés ideje: 2021. december 15. http://dds.edu.ua/articles/2/slovo/2006/465-pseudosobor.html.

Bortsurkiv, Bohdan (1993). Az Ukrán Görögkatolikus Egyház a katakombákban (1946-1989) (Українська греко-католииька иерква в катакомбах [1946-1989]). In Jaroslav Hrytsak és Boris Gudzjak (szerk.), Kovcseh, Egyháztörténelmi cikkgyüjtemény. I. (Ковчег. Збірник статей з церковної історії. - Число I). Lemberg: Az Ivan Franko Lembergi Állami Egyetem Történelemtudományi Kutatóintézete - Egyháztörténeti Intézet, 113-152. o.

Bublyk, Taras (2012). A görögkatolikus hivek szerepe az Ukrán Görögkatolikus Egyház legalizálásáért zajló mozgalomban, az UGKE védelmi bizottság példáján (Участь греко-католицького мирянства у русі за легалізацію УГКЦ: на прикладі діяльності Комітету захисту УГКЦ). Zaporizsje: Zaporizsjei Egyetem, 302-309. o.

Fenych, Volodimir (2019). Az ungvári egyházi unió görögkatolikus hívei: mitoszok, sztereotípiák, reáliák (Греко-католики ужгородської унійної традииї: міфи, стереотипи, реаліï). Ungvár: V. Padjak Könyvkiadó, 248. o.

Gurkina, Szvitlana (szerk.) (2014). A Feltámadás fényéhez a katakombák tövisein át. Az Ukrán Görögkatolikus Egyház ellenállása és legalizálása (До Світла Воскресіння крізь терни катакомб. Підпільна діяльність та легалізація УГКЦ). Lemberg: Ukrán Katolikus Egyetemi Kiadó, 2014.

John Paul II (1988). Magnum Baptismi Donum. Catholic Culture. A letöltés ideje: 2021. december 15. https://www.catholicculture.org/culture/library/view. cfm?recnum $=3701$.

Keleher, Serge (1993). Passion and Resurrection - the Greek-Catholic Church in Soviet Ukraine 1939-1989. Lemberg: Stauropegion, 283. o.

Kobuta, Stepan (1999). Az UKGE legalizálása 1987-1991 (Politikai aspektus) (Легалізачї УГКЦ 1987-1991 рр. (Політичний аспект). Newright. 


\section{Külïgyi Szemle}

primordial.org. A letöltés ideje: 2021. december 15. http://newright.primordial. org.ua/kobuta.htm.

Kossej, Jurij (2000). Szemedi János püspök - Kárpátalja lelkész alakja (Владика Іоанн Семедій - духовний діяч Закарпаття). Ungvár: Kárpátalja, 156. o.

Kossej, Jurij (2001). Joszif Holovach segédpüspök és érdemei (Помічний єпископ Йосиф Головач і його заслуги). Ungvár: Spektral LTD, 650. o.

RISU (2011). Az Ukrán Görögkatolikus Egyház. Történelem (Az 1980-as évek elejétől napjainkig) (Українська ГКЦ. Історія (к. 80-х років ХХ сm. - до наших днів). A letöltés ideje: 2021. december 15. https://risu.ua/ukrajinskagreko-katolicka-cerkva-istoriya-kinec-80-h-rokiv-hh-stolittya-do-nashihdniv_n52318.

The Ukrainian Weekly (1989). One Churches. A letöltés ideje: 2021. december 15. https://www.ukrweekly.com/archive/1989/The Ukrainian_Weekly_1989-53. pdf, 8-9. o. 